\title{
Metaphors in Sundanese Restaurants Naming
}

\author{
Eva Tuckyta Sari Sujatna, Kasno Pamungkas, and Heriyanto
}

\begin{abstract}
There are a number of research on metaphor have been done by the researchers in the world but it is very limited research on metaphor Sundanese restaurants naming. Sundanese is one of the tribes in Indonesia. It is the second number of speakers in Indonesia. The word of Sundanese can refer to language, culture, also people. The word Sundanese in this research refers to language. The writers obtained the data to identify the types of metaphor applied in the Sundanese restaurants naming. It is shown that there are two type of metaphors found, they are, dead metaphor and standard metaphor. From the data analyzed, it is found that the number of dead metaphor is $15 \%$ while the standard metaphor is $85 \%$.
\end{abstract}

Keywords: Metaphor, Sundanese Restaurant Naming, Dead Metaphor, standard Metaphor

\section{INTRODUCTION}

The word Sundanese can refer to tribe, language, people, or culture. The word Sundanese mentioned in this paper refers to language. As a language, Sundanese is spoken by 39 million people as the speakers or about $15 \%$ of Indonesian citizens. It is one of the biggest tribes in Indonesia: relating to the number of speakers, it is the second rank after Javanese. Geographically, Sundanese is spoken by the speakers in Jawa Barat area. As one of the provinces in Java Island, Jawa Barat has 27cities and regencies. Jawa Barat is well known as a rich province of culinary, especially Bandung as the capital city of the province. As we know, culinary can be the one of the tourism objects besides the destination. Many people visit Bandung to enjoy the culinary, since they consider Sundanese culinary has special taste based on the traditional recipe. The tourists or visitors visit to the destinations and enjoy the culinary, not only the taste of the food but also sometimes the name of the restaurant. The unique name of restaurants can attract the consumer to spend their money in enjoying the culinary. The local language applied in the restaurant naming to make the restaurant seems more traditional. In naming the restaurants, besides using the local language (in this case Sundanese) the owner also apply the morphological processes, such as borrowing, blending, compounding, or even metaphor to make the restaurants naming are more attractive. By naming the restaurant more attractive it can increase the tourists coming to Indonesia.

Alikina and Mishlanova [1] did their research on metaphor and tourism in Rusia. Referring to their research, this paper tries to figure out the metaphor in Sundanese restaurant naming in Jawa Barat.

Eva Tuckyta Sari Sujatna, Kasno Pamungkas, Heriyanto are with Universitas Padjadjaran, Bandung - Indonesia

eva.tuckyta@unpad.ac.id, kasno.pamungkas@unpad.ac.id,

heriyanto@unpad.ac.id
The aims of the research are to clas sify the type of metaphor in Sundanese restaurants naming and to categorize the word formation of Sundanese restaurants naming.

\section{METHODOLOGY}

The data collected are the names of restaurants in Jawa Barat to represent Sundanese geography. In this case, the writers not only chose the Sundanese geography but also the Sundanese naming. From the data collected (it is about twenty Sundanese restaurant naming), the writers classified into the types of metaphor. Besides the type of metaphor, the writers also classified the data into the morphological process of the restaurant naming.

\section{THEORETICAL FRAMEWORK}

Metaphor as the first key word of the research, according to Lakoff in Sujatna [2], is "for most people a device of the poetic imagination and the rhetorical flourish- a matter of extraordinary rather than ordinary language." It means that metaphor used an extraordinary language; it is not the common one, the imagination is needed in understanding a metaphor. Richards in Donoghue [3] argues that metaphor is "a shift, a carrying over a word from its normal use to a new use". Metaphor is a figure of speech; it is closer to emotion since emotive words that usually used in the metaphor can express someone's feeling or emotion. Lakoff and Johns on [4] stated that "...that metaphor is pervasive in everyday life not just in language but in thought and action." The relationship between metaphor and culture are very close. As Kovecses [5] argued "...metaphor and culture can be seen intimately linked. After all, metaphor can be viewed as the ornamental use of language." So that, metaphor could be found in the restaurant naming, in this research in Sundanese restaurant naming, it is used to persuade the visitor for coming to enjoy the food and beverages.

In line with Lakoff and Johnson [4], Lakoff and Richard in Donoghue [3], Newmark in Oliynyk [6] classified metaphor into six types of metaphors. They are dead metaphor, cliché metaphor, standard or stock metaphor, recent metaphor, and adapted metaphor. The six classifications are applied into the types of metaphor in the data of Sundanese restaurant naming.

Oliynyk defined "Dead metaphors are metaphors without figurative meaning. Dead metaphors often used when describing the time and space, geographical objects and activities of people. Metaphors are often words that distinguish parts of the body, natural phenomena, and abstract astronomical concepts." The following is the example of dead metaphor in English: The house is at the foot of the mountain.

The following example describes that the word foot as the part of human body is used by the mountain. 
Besides the dead metaphor, the second type is metaphorcliché. According to Newmark in Oliynyk [6], "Metaphor clichés are metaphors that lost their aesthetic sense and are used only in connotative function, in order to express thoughts more clearly often with a larger share of emotions." He describes the metaphor - cliché in the following:

The County School will in effect become not a backwater but a breakthrough in educational development which will set trends for the future. In this its traditions will help and it may well become a jewel in the crown of the county's education.

The words backwater, breakthrough, set trends, traditions, and a jewel in the crown are metaphors.

The third type of metaphor is standard or stock metaphor. This type, according to Newmark in Oliynyk [6], "are metaphors which are effective means of describing concrete or abstract concepts, which has an emotional impact on the reader and unlike dead metaphors have active aesthetic function." Later on Newmark in Oliynyk added that the metaphor may be outdated or be used only by members of a particular social class or age as described in It is raining cats and dogs.

The fourth type is adapted metaphor. This type of metaphor, according to Newmark in Oliynyk, he considered adapted metaphors to be author's metaphorical occasionalisms.

The fifth type is considered as recent metaphors or metaphorical neologisms, many of which are "anonymous" and is widely spread in the original language. According to Newmark, it is called neologism since the words used are new metaphors or renew themselves in language. The example is the word walkman which is taken from the words walk and man and the metaphor has a new meaning 'portable cassette player'.

The six type of Newmark's in Oliynyk is considered as original metaphors to be individual author's metaphors used by the author individually and are not common in everyday usage. Newmark believed that author's metaphors should be rendered as close as possible to the original, because: a) the author's metaphor manifests individual style and personality of the author and b) the author's metaphors contribute to the enrichment of the vocabulary of the target language.

In naming restaurants, it involves word formation. The words formed have their own philosophy to attract the visitors coming to the restaurants, it also happens to Sundanese restaurants. As Marchand [7] argued that word formation is "the branch of the science of language which studies the pattern on which a language forms new lexical units, i.e. words." Besides Marchand's argumentation, McMannis [8] divided the word formation as follows:

a) Derivation, English has a number of derivational morphemes which we use to derive words. There are prefixes or suffixes, such as, like - dislike, friend friendly, serum-antiserum, etc.

b) Compounding, a compound is a word formed by combination of two independent words. The part of a compound can be free morphemes, derived words, or other compounds, such as, girlfriend, lifeguard, blackboard, etc.

c) Acronym, are formed by taking the initial sounds (or letters) of the words or phrase and uniting them into combination which it itself pronounceable as a separate word, such as,NATO, ABRI, UN, etc.

d) Back Formation, makes use of a process called analogy to derive new words, but in rather backwards manner, such as, television $\rightarrow$ televise

e) Blending, is a combination of the parts of two words, usually in the beginning of one words and the end of another, such as, smoke + fog: smog, breakfast + lunch: brunch, etc.

f) Clipping, frequently we shorten words without paying attention to the derivational morphology of the word(or related words). It can be shorten in the beginning (aphesis), in the middle (syncope), and at the end (apocope) such as, van from caravan, ne'er fromnever, dorm from dormitory.

g) Coinage, words may also be created without using any of the methods described above and without employing any other word or word parts already in existence, such as, Kodak, Exxon, etc.

h) Functional Shift, a new word may be created simply by shifting the part of speech to another one without changing the formof the word, such as, run, laugh as the nouns and verbs.

i) Morphological misanalysis, sometimes people hear a word and misanalyse it either because they "hear" a familiar word or morpheme in the word, or for other, unknown reasons, such as, -burger in hamburger is not from ham + burger, it is the clipping from Hamburger steak, it also happens to cheeseburger, salmonburger, beefburger, etc.

j) Proper names, many places, inventions, activities are named for persons somehow connected with them, such as, City of Washington D.C. from the name George Washington, District of Columbia from Christopher Columbus, etc.

From the ten types of word formations, the writers found three types in the Sundanese restaurant naming data. Compounding as the word formation is found in both dead and standard metaphor, while coinage and blending are in standard metaphor.

\section{DISCUSSION}

The twenty data are taken from twenty different texts such as, brochure or leaflet of restaurant promotion in Jawa barat area. Fromthe sixNewmark's [9] classification, it is found two types of metaphors in the Sundanese restaurant naming as the data. They are dead metaphor and standard metaphor. From each metaphor, the writers also observe the morphological processes of the Sundanese restaurant naming since the naming commonly are structured from two or more words.

\subsection{Dead Metaphor in Sundanese Restaurant Naming}

From the twenty data collected, there are three Sundanese restaurants naming as dead metaphor. The three Sundanese restaurants naming are structured from compounding as described in the following data.

(1) Raja Rasa

(2) Raja Sunda

(3) Sindang Reret

The Sundanese restaurant naming in data (1) - (3) are taken fromSundanese language. They classified into dead metaphor 
since the three names are metaphors without figurative meaning. The dead metaphor mentioned in data (1) taken from the word Raja means 'king' and rasa means 'taste' literally 'King of taste'. It also happens to data (2) Raja means 'King' and Sunda means 'Sundanese'. The word Sundanese can refer to Sundanese as people, culture or food. So that, the restaurant naming Raja Sunda means 'King of Sundanese'. The data (3) is also classified into dead metaphor since it describes the activities of people. The words sindang means 'come' and reret means 's ee', literally means 'come to see or to enjoy' in this case 'come to enjoy the food'.

Relating to the morphological process or word formation, the three naming are categorized into compounding. The three compounding are formed by combination of two independent words: raja and rasa for data (1), raja and Sunda for data (2), and sindang and reret for data (3).

\subsection{Standard Metaphor in Sundanese Restaurant Naming}

From the twenty Sundanese restaurant naming data collected, it is found seventeen data as standard metaphor. Relating to the word formation, the seventeen Sundanese restaurants naming as standard metaphor, twelve data are compounding, four data are categorized as coinage, and one data is categorized as blending as described in the following data.
(4) Panorama Elok
(5) Racik Desa
(6) Sari Cobek
(7) Bumbu Desa
(8) Rumah Nenek
(9) Dapur Kampung
(10) Boemi Mitoha
(11) Kampung Sawah
(12) Kampung Daun
(13) Alas Daun
(14) Saung Balakecarakan
(15) Sambel Hejo
(16) Resto Sambara
(17) Bancakan
(18) Ponyo
(19) Mang Kabayan
(20) Ampera

From the seventeen Sundanese restaurants naming clas sified into standard metaphor, the above data (4) - (15) are categorized into compounding, data (16) - (19) are categorized into coinage, and data (20) is categorized as blending.

All the data above are classified into standard metaphor since the seventeen Sundanese restaurants naming data are metaphors which are effective means of describing concrete or abstract concepts, which has an emotional impact on the reader and unlike dead metaphors have active aesthetic function.

Relating to the word formation, the data Panorama Elok (4) is formed by two words panorama and elok. The word Panorama means 'scenery' and elok means 'beautiful'. The two words are not Sundanese words although the restaurant is the Sundanese restaurants. The two words are taken from Bahasa Indonesia words.

Data (5) Racik Desa as the standard metaphor is taken from the two free morphemes. The data (5) has similarity with data (4). Both free morphemes Racik means 'mix' and Desa means 'village' are taken from Bahasa Indonesia.
Data (6) is also derived from two free morphemes. They are Sari and Cobek. Sari means 'main (content)' is taken from Bahas a Indonesia and cobek means 'plate made from stone or wood' is taken from Javanese. So that, the compounding Sari Cobek is the combination of two free morphemes is taken from Bahasa Indonesia and Javanese words.

Data (7) Bumbu Desa has a similar word formation with data (4) and (5). The data is formed by two free morphemes, the free morpheme Bumbu means 'spicy' and the free morpheme Desa means 'village' are taken from Bahasa Indonesia words.

The morphological process of data (8) is similar to data (4), (5), and (7). The compounding Rumah Nenek is derived from the free morpheme Rumah means 'house' and Nenek means 'grandmother'. Both the free morphemes are taken from Bahasa Indonesia words.

Data (9) Dapur Kampung is a compounding from two free morphemes Dapur means 'kitchen' and kampong means 'village'. The word Dapur is taken from Bahasa Indonesia while the word Kampung is taken from Sundanese word.

Data (10) has different word formation from earlier data mentioned. The data (10) Boemi Mitoha is two free morphemes taken from Sundanese. The word Boemi means 'house' and the word Mitoha means 'mother/ father in law'

Data (11) and data (12) have similarity with data (10). The two data are formed by two free morphemes. Data (11) Kampung means 'village' and Sawah means 'rice field' while the word Daun in data (12) means 'leaf'. Both compounding Kampung Sawah and Kampong Daun are taken from Sundanese words.

Data (13) is derived from two free morphemes. The word Alas means 'plate' and Daun means 'leaf'. The word Alas is taken from Bahasa Indonesia while the word Daun is taken from Sundanese word.

Data (14) Saung Balakecrakan is similar to data (10), (11), and (12); they derived from Sundanese words. The word Saung in data (14) means 'hut' and Balakecrakan means 'messy'.

Data (15) Sambel Hejo as the last data in compounding is derived from the free morpheme Sambel means 'condiment' and the word Hejo means 'green (chili)'. The data is similar to data (10), (11), (12), and (14).

Data (16) - (19) are classified into standard metaphor categorizing Coinage since the words may also be created without using any of the methods described above and without employing any other word or word parts already in existence.

Data (20) is the last data as standard metaphor which derived fromblending process. The word Ampera is derived from(m)am(man means 'eating')+ pera (pera means 'rice'). So, the word Ampera means 'eating rice' as the main course for Sundanese people.

\section{CONCLUSION}

From the data analysis, the metaphor of Sundanese restaurant naming is $15 \%$ is dead metaphor and $85 \%$ is standard metaphor as described in the following pie chart. 
[9] Newmark, Peter. A Textbook of Translation. Singapore: Prentice Hall, 1988.

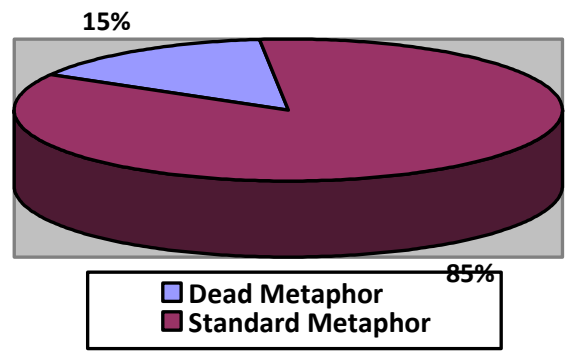

From the $15 \%$ of dead metaphor, all of the word formation is compounding while from the $85 \%$ of standard metaphor; $70.6 \%$ is compounding, $23.5 \%$ is coinage, and $5.9 \%$ is blending, as described in the following pie chart.

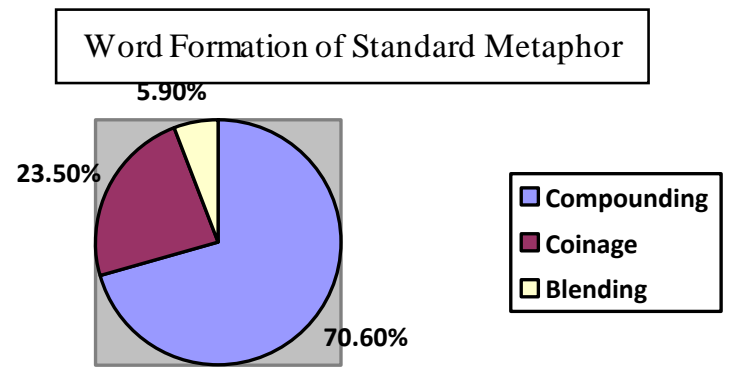

From the compounding in the dead metaphor, the all free morphemes are taken from Sundanese words while the compounding in the standard metaphors is various. The twelve compounding data in the standard metaphor are various. The data (4), (5), (7), and (8) are taken from Bahasa Indonesia free morphemes, the data (10), (11), (12), (14), and (15) are taken from Sundanese, the data (9) and (13) are taken from the combination Bahasa Indonesia and Sundanese, while the data (6) is taken from the combination of Bahas a Indonesia and Javanese.

\section{REFERENCES}

[1] E. Alikina and S. Mishlanova. "Metaphor Modelling in Tourism Discourse: Comparative Aspect." European Symposium on Language for Special Purposes. Perm: Perm State National Research University, 2011: 314-325.

[2] Sujatna, Eva Tuckyta Sari, Heriyanto, Kasno Pamungkas. Metaphor in Jawa Barat Tourism Promotion. International Journal of Humanities and Social Sciences (IJHSS), 2015: 15-23

[3] Donoghue, Denis. Metaphor. London: Harvard University Press, 2014. https://doi.org/10.4159/harvard.9780674419483

[4] Lakoff, George, and Mark Johnson. Metaphors We Live by. Chicago: The University of Chicago Press, 1980.

[5] Kovecses, Zoltan. Metaphor and Emotion. New York: Cambridge University Press, 2007.

[6] Oliynyk, Tetyana. "Metaphor Translation Methods." International Journal of Applied Science and Technology, 2014: 123-126.

[7] Marchand, H. The Categories and Types of Present-day English Word Formation. 2-nd Edition. Munich: C. H. Becksche Verlaegsbuchhandlung, 1992.

[8] McManish, C et al. Language Files. United States of America: Advocate Publishing Group, 1987. 